\title{
Pharmacogenetics of Extraordinary Responses to 5-FU/Cisplatin Chemotherapy in Advanced Gastric Cancer - Report of 2 Cases
}

\author{
Christine Wolschke $^{\mathrm{a}} \quad$ Eray Goekkurt $^{\mathrm{b}} \quad$ Salah-Eddin Al-Batran ${ }^{\mathrm{c}} \quad$ Dieter Kurt Hossfeld $^{\mathrm{a}}$ \\ Jan Stoehlmacher ${ }^{\mathrm{b}}$ \\ a Medizinische Klinik II, Onkologie, Hämatologie und Knochenmarkstransplantation, Universitätsklinikum Hamburg-Eppendorf, \\ ${ }^{b}$ Medizinische Klinik und Poliklinik I, Universitätsklinikum Carl Gustav Carus der TU Dresden, \\ c Medizinische Klinik II, Onkologie/Hämatologie, Krankenhaus Nordwest Frankfurt/M., Germany
}

Key Words

Gastric cancer · Pharmacogenetics · Chemotherapy

\section{Summary}

Background: Gastric cancer is often diagnosed in the metastatic stage, and only $10 \%$ of patients survive for as long as 2 years. Current chemotherapy regimens show significant treatment-related toxicities. It is crucial to identify the patients that will benefit most from certain chemotherapy regimens in order to avoid unnecessary side effects. Patients and Methods: 2 patients with advanced gastric cancer repeatedly received 5-FU/cisplatin combination chemotherapy. Genomic DNA was extracted from tumor tissue and mononuclear blood cells. Genotype analysis of genes of metabolizing and DNA repair enzymes was carried out using a PCR-RFLP technique. Direct sequencing was used to identify mutations of the gene dihydropyrimidine dehydrogenase (DPD). Results: Prolonged survival of 51 and 29 months, respectively were observed in our 2 patients. Both patients were positive for genotypes of thymidylate synthase the target enzyme of 5-FU - that are associated with improved drug response. DPD variants connected with increased toxicity were not observed. However, both patients also showed genotypes in cisplatin metabolizing enzymes which enhance the effect of the drug. Conclusion: Genotype analysis in drug metabolizing enzymes of 5-FU and cisplatin provide a possible explanation for extraordinary therapy effects observed in 2 patients with advanced gastric cancer.

\author{
Schlüsselwörter \\ Magenkarzinom · Pharmakogenetik · Chemotherapie
}

\section{Zusammenfassung}

Hintergrund: Das Magenkarzinom wird häufig im fortgeschrittenen Stadium diagnostiziert, und nur etwa $10 \%$ der Patienten überleben 2 Jahre. Aktuelle Chemotherapien zeigen eine hohe therapiebedingte Toxizität. Es ist daher von großer Bedeutung, diejenigen Patienten zu identifizieren, die von einer bestimmten Therapie profitieren, um anderen Patienten die Nebenwirkungen einer solchen Therapie zu ersparen. Patienten und Methoden: 2 Patienten mit fortgeschrittenem Magenkarzinom erhielten wiederholt eine Kombinationschemotherapie aus 5-FU/Cisplatin. Genomische DNS wurde aus Tumorgewebe und Leukozyten isoliert. Genotypanalysen von Genen, die am Metabolismus der Substanzen und am DNS-Reparaturprozess beteiligt sind, wurden mithilfe einer PCRRFLP-Methode durchgeführt. Das Gen der Dihydropyrimidindehydrogenase (DPD) wurde direkt sequenziert. Ergebnisse: Beide Patienten zeigten ein deutlich verlängertes Überleben von 51 bzw. 29 Monaten. Genotypen des 5-FU-Zielenzyms Thymidylatsynthase, die mit einem verbesserten Ansprechen assoziiert sind, konnten in beiden Patienten nachgewiesen werden. DPD-Varianten, die mit einer erhöhten Toxizität verbunden sind, wurden nicht beobachtet. Zusätzlich konnten bei beiden Patienten Genotypen in Cisplatin metabolisierenden Genen gefunden werden, die eine prolongierte Wirkung der Substanz bedingen. Schlussfolgerungen: Durch Genotypanalysen in Genen des 5-FU- und Cisplatin-Metabolismus konnte ein spezifisches pharmakogenetisches Profil identifiziert werden, das möglicherweise die Ursache eines außergewöhnlich guten Therapieeffektes in 2 Patienten mit fortgeschrittenem Magenkarzinom ist.

\begin{tabular}{ll}
\hline KARGER & @ 2005 S. Karger GmbH, Freiburg \\
Fax +497614520714 & Accessible online at: \\
$\begin{array}{l}\text { E-mail Information@Karger.de } \\
\text { www.karger.com }\end{array}$ & www.karger.com/onk \\
&
\end{tabular}

Dr. med. Jan Stöhlmacher

Universitätsklinikum Carl Gustav Carus der TU Dresden

Medizinische Klinik und Poliklinik I

Fetscherstrasse 74, 01307 Dresden, Germany

Tel. +49 351 4585-601, Fax -362

E-mail jan.stoehlmacher@uniklinikum-dresden.de 


\section{Introduction}

Gastric cancer is often diagnosed in advanced stages of the disease and is therefore associated with a poor prognosis. The median survival is as little as $6-8$ months, and less than $10 \%$ of patients with metastatic disease survive for as long as 2 years [1]. Current treatment regimens - including epirubicin, methotrexat, platinum and 5-FU - are often highly toxic [2]. Recently, additional drugs such as irinotecan, taxanes and cetuximab have been introduced to palliative treatment of gastric cancer. The high toxicity and limited benefits of current chemotherapies for most gastric cancer patients require a careful selection of patients suitable for treatment.

Currently, there are no efficient clinical, pathological or molecular markers to distinguish between responders and non-responders in relation to certain chemotherapy regimens used in gastric cancer. Pharmacogenetic analysis utilizes information on metabolic variations of administered chemotherapeutic drugs to predict clinical outcome. A combination of cisplatin and 5-FU is widely used in gastric cancer patients. Several functional genetic polymorphisms have been described for metabolizing enzymes of these substances such as thymidylate synthase (TS), glutathione S-transferase (GST) and excision cross complementing gene (ERCC) [3].

Here, we report on an extraordinary response to 5-FU/cisplatin combination chemotherapy in 2 gastric cancer patients. We further provide information on pharmacogenetic analysis demonstrating its potential as a predictor for clinical outcome in gastric cancer.

\section{Case Reports}

\section{Clinical Observations}

A 51-year-old female patient (patient A) was diagnosed with advanced gastric cancer in February 2001. Initial surgery revealed advanced peritoneal carcinomatosis, and parts of the omentum, the adnexes and a Krukenberg's tumor were removed. A postoperative CT scan demonstrated advanced peritoneal carcinomatosis and a thickening of the stomach wall, but no further distant metastases. 6 weeks after surgery, a combination chemotherapy of 5-FU and cisplatin was initiated. The patient received $200 \mathrm{mg} / \mathrm{m}^{2}$ leucovorin followed by $2000 \mathrm{mg} / \mathrm{m}^{2} 5$-FU once weekly and $50 \mathrm{mg} / \mathrm{m}^{2}$ cisplatin every other week for 6 weeks (one cycle). Tumor assessment after 3 cycles of chemotherapy revealed that all tumorrelated lesions had disappeared. Approximately 1 year after having been diagnosed, the patient once again showed tumor progression and a thickening of the stomach wall. The patient received 2 more cycles of chemotherapy followed by a Billroth II resection and remained diseasefree for 10 months. In May 2004, the disease recurred in the remaining stomach and the abdominal cavity. The patient received 3 more cycles of 5-FU/cisplatin and did not show any disease progression until November 2004. At that point, the chemotherapy regimen was changed to 5-FU, leucovorin and mitomycin $\mathrm{C}$. The patient last visited the hospital in May 2005, 51 months after the initial diagnosis of stomach cancer and peritoneal carcinomatosis. During the entire treatment, no major hematological or gastrointestinal toxicities were observed. The patient did not demonstrate any hepatic or renal failure.
Patient B, a 60-year-old female patient, was diagnosed with stomach cancer in December 2002 after having reported constantly increasing digestive problems and pains in the upper abdomen. Clinical examination revealed a $22 \times 26 \mathrm{~mm}$ mass on the right abdominal wall. The stomach was removed ( $\mathrm{R} 2$ resection) in an attempt to prevent gastric outlet obstruction, and examination of biopsies taken from the mass on the abdominal wall confirmed metastasized stomach cancer. 7 weeks after surgery, palliative chemotherapy with 5-FU/cisplatin as described above was started. After 2 cycles of combination chemotherapy, CT scans showed only minimal residual disease, and complete response was obtained after 3 cycles, followed by a disease-free interval of 23 months. 1 month prior to a scheduled follow-up visit at the outpatient clinic, patient B noticed significant weight loss and new abdominal pain. In February 2005, the disease progressed including retroperitoneal lymph node metastases, and the patient was put back on 5-FU/cisplatin combination chemotherapy. Upon last patient contact in May 2005, no disease progression was observed. In addition to the remarkable response to the treatment, patient $\mathrm{B}$ experienced severe side effects in the form of WHO grade-III diarrhea. The diarrhea was managed with saline infusions and oral loperamide. Since the patient had responded well to the first therapy cycle, we aimed to continue the chemotherapy regimen. Tumor response was evaluated according to the RECIST criteria. Toxicity was graded based on the WHO toxicity criteria. Both patients gave informed consent to perform genotype analysis. Patients $\mathrm{A}$ and $\mathrm{B}$ showed remarkable responses to 5-FU/cisplatin chemotherapy with prolonged time to progression and survival times of 51 months and 29 months, respectively.

\section{Pathological Examination and Genotype Analysis}

Patient A showed a poorly differentiated adenocarcinoma of the stomach. The tumor of patient B was moderately differentiated. For genotyping, DNA was extracted from both tumor sections and peripheral mononuclear cells. Genotyping was performed using a PCR based restriction fragment length polymorphism (RFLP) technique and direct sequencing [4, 5]. Genetic polymorphisms were examined in the following genes involved in the metabolism of cisplatin and 5-FU: thymidylate synthase (TS), dihydropyrimidine dehydrogenase (DPD), glutathione S-transferase P1 (GSTP1) and excision repair cross complementing gene 1 (ERCC1). The genotypes are presented in table 1. Between tumor and host DNA, no genotype differences were observed.

\section{Discussion}

Both patients experienced prolonged survival and benefited significantly from repeated 5-FU/cisplatin combination chemotherapy. We analyzed functional genetic variations in the DNA sequence of metabolizing enzymes of 5-FU (TS-3', TS-5', DPD) and cisplatin (GSTP1-105, ERCC1-118).

The TS-3' 1494del6 (-) variant and the TS-5' 2R and 3RC variants have been associated with decreased TS expression [6, 7]. Several reports link low TS expression levels to a favourable outcome of 5-FU based chemotherapy in gastrointestinal tumors including gastric cancer [8-10]. Patient A had TS genotypes (TS-3' and TS-5') associated with decreased TS levels, which may have enhanced the 5-FU action. Interestingly, no severe side effects were observed in this patient. High-grade hematological and gastrointestinal side effects have been described in patients with DPD deficiency [11]. The polymorphism in exon 14 of the DPD gene, that shows the highest frequency of known DPD polymorphisms and has been linked to 
Table 1. Genotypes of patient A and patient B

\begin{tabular}{lllllll}
\hline & TS-3 & TS-5 & TS-SNP & ERCC1-118 & GSTP1-105 & DPD \\
\hline Patient A & $-/-$ & 2R/3R & C & C/T & Val/Val & $\mathrm{wt} / \mathrm{wt}$ \\
Patient B & $-/+$ & 2R/3R & C & T/T & Ile/Val & $\mathrm{wt} / \mathrm{wt}$ \\
\hline
\end{tabular}

Val: valine, Ile: isoleucin, wt: wild type, (-): TS-3’ 1494del6, (+): TS-3’ 1494ins6.

even fatal toxicity, was not identified in our patients [4]. The dramatic side effects seen in DPD deficient patients are due to accumulation of active metabolites of 5-FU, since DPD clears more than $80 \%$ of 5 -FU in the liver. However, patient B experienced grade-III diarrhea. Such an association between 5-FU toxicity and TS genotype contrary to the effects on the tumor has been reported before [12].

Although both patients harbored TS genotypes favoring tumor response and increased toxicity, only patient B demonstrated significant side effects. This reflects obvious limitations of a pharmacogenetic approach focusing on key enzymes. Functional variations in additional players such as methylentetrahydrofolate reductase (MTHFR) or dUTP dinucleotidohydrolase (dUTPase) may have neutralized the 5-FU effect in patient A but enhanced its power in patient B. Furthermore, it has to be considered that responses seen in both patients are the results of a combination chemotherapy of 5-FU and cisplatin.

The detoxifying effect of GSTP1 on cisplatin is well established [13]. The valine variant of a single nucleotide polymorphism (SNP) within exon 5 of the GSTP1 gene could be linked to superior survival in colorectal cancer patients that received 5-FU/platinum chemotherapy [14]. The favorable GSTP1 variant was detected in its homozygous form in patient A. Patient
B was heterozygous for this polymorphism. In addition, both patients demonstrated ERCC1 genotypes that have been linked to impaired DNA repair capacity [15]. Taken together, both patients demonstrated genotypes that enhance the platinum effect due to less efficient detoxification of the administrated drug (GSTP1 genotype) and reduced repair of cisplatin-induced DNA adducts by the nucleotide excision repair pathway (ERCC1 genotype).

In conclusion, both patients with advanced gastric cancer experienced significant clinical benefit and extraordinary prolonged survival following 5-FU/cisplatin combination chemotherapy. Pharmacogenetic analysis of metabolizing enzymes provided some insight into possible mechanisms underlying this success. Since new drugs such as oxaliplatin [16] and docetaxel [17] have recently been shown to be effective in the treatment of patients with gastric cancer, pharmacogenetics appear to be a promising tool to tailor chemotherapy in these patients in the future.

The clinical impact of pharmacogenetic analysis in patients with advanced gastric cancer is currently evaluated in large clinical trials. Our preliminary findings regarding polymorphisms in the TS and GSTP1 gene and response to 5-FU/cisplatin chemotherapy in these patients need to be confirmed before this information should be incorporated into clinical routine.

\section{References}

1 Janunger KG, Hafstrom L, Nygren P, Glimelius B; SBU-group. Swedish Council of Technology Assessment in Health Care: A systematic overview of chemotherapy effects in gastric cancer. Acta Oncol 2001;40:309-326.

2 Webb A, Cunningham D, Scarffe JH, Harper P, Norman A, Joffe JK, Hughes M, Mansi J, Findlay M, Hill A, Oates J, Nicolson M, Hickish T, O'Brien M, Iveson T, Watson M, Underhill C, Wardley A, Meehan M: Randomized trial comparing epirubicin, cisplatin, and fluorouracil versus fluorouracil, doxorubicin, and methotrexate in advanced esophagogastric cancer. J Clin Oncol 1997;15:261-267.

3 Stoehlmacher J: Pharmacogenetics in gastrointestinal tumors. Onkologie 2005;28:435-440.

4 van Kuilenburg AB, Muller EW, Haasjes J, Meinsma R, Zoetekouw L, Waterham HR, Baas F, Richel DJ, van Gennip AH: Lethal outcome of a patient with a complete dihydropyrimidine dehydrogenase (DPD) deficiency after administration of 5-fluorouracil: frequency of the common IVS14+1G $>$ A mutation causing DPD deficiency. Clin Cancer Res 2001;7:1149-1153.
5 Stoehlmacher J, Park DJ, Zhang W, Yang D, Groshen S, Zahedy S, Lenz HJ: A multivariate analysis of genomic polymorphisms: prediction of clinical outcome to 5-FU/oxaliplatin combination chemotherapy in refractory colorectal cancer. Br J Cancer 2004;91:344-354.

6 Mandola MV, Stoehlmacher J, Zhang W, Groshen S, Yu MC, Iqbal S, Lenz HJ, Ladner RD: A 6 bp polymorphism in the thymidylate synthase gene causes message instability and is associated with decreased intratumoral TS mRNA levels. Pharmacogenetics 2004;14:319-327.

7 Mandola MV, Stoehlmacher J, Muller-Weeks S, Cesarone G, Yu MC, Lenz HJ, Ladner RD: A novel single nucleotide polymorphism within the 5' tandem repeat polymorphism of the thymidylate synthase gene abolishes USF-1 binding and alters transcriptional activity. Cancer Res. 2003;63:2898-2904.

8 Metzger R, Leichman CG, Danenberg KD, Danenberg PV, Lenz HJ, Hayashi K, Groshen S, Salonga D, Cohen H, Laine L, Crookes P, Silberman H, Baranda J, Konda B, Leichman L: ERCC1 mRNA levels complement thymidylate synthase mRNA levels in predicting response and survival for gastric cancer patients receiving combination cisplatin and fluorouracil chemotherapy. J Clin Oncol 1998;16: 309-316.
9 Leichman CG, Lenz HJ, Leichman L, Danenberg K, Baranda J, Groshen S, Boswell W, Metzger R, Tan M, Danenberg PV: Quantitation of intratumoral thymidylate synthase expression predicts for disseminated colorectal cancer response and resistance to protracted-infusion fluorouracil and weekly leucovorin. J Clin Oncol 1997;15:3223-3229.

10 Marcuello E, Altes A, Del Rio E, Cesar A, Menoyo A, Baiget M: Single nucleotide polymorphism in the $5^{6}$ tandem repeat sequenze of thymidylate synthase gene predicts for response to fluorouracil based chemotherapy in advanced colorectal cancer patients. Int J Cancer 2004;112: 733-737.

11 Van Kuilenburg AB, Meinsma R, Zoetekouw L, Van Gennip AH: High prevalence of the IVS14 + $1 \mathrm{G}>\mathrm{A}$ mutation in the dihydropyrimidine dehydrogenase gene of patients with severe 5-fluorouracilassociated toxicity. Pharmacogenetics 2002;12:555558.

12 Pullarkat ST, Stoehlmacher J, Ghaderi V, Xiong YP, Ingles SA, Sherrod A, Warren R, Tsao-Wei D, Groshen S, Lenz HJ: Thymidylate synthase gene polymorphism determines response and toxicity of 5-FU chemotherapy. Pharmacogenomics J 2001;1: 65-70. 
13 Tsuchida S and Sato K: Glutathion transferases and cancer. Crit Rev Biochem Mol Biol 1992;27: 337-384.

14 Stoehlmacher J, Park DJ, Zhang W, Groshen S, Tsao-Wei DD, Yu MC, Lenz HJ: Association between glutathione S-transferase P1, T1, and M1 genetic polymorphism and survival of patients with metastatic colorectal cancer: J Natl Cancer Inst 2002;94:936-942.
15 Reed E: Platinum-DNA adduct, nucleotide excision repair and platinum based anti-cancer chemotherapy. Cancer Treat Rev 1998;24:331-344.

16 Al-Batran S, Atmaca A, Hegewisch-Becker S, Jaeger D, Hahnfeld S, Rummel JM, Seipelt G, Rost A, Orth J, Knuth J, Jaeger E: Phase II trial of biweekly infusional fluorouracil, folinic acid, and oxaliplatin in patients with advanced gastric cancer. $\mathrm{J}$ Clin Oncol 2004;22:658-663.
17 Ajani JA, Van Cutsem E, Moiseyenko V, Tjulandin S, Fodor M, Majlis A, Boni C, Zuber E, Blattmann E: Docetaxel (D), cisplatin, 5-fluorouracil compared to cisplatin (C) and 5-fluorouracil (F) for chemotherapy-naive patients with metastatic or locally recurrent, unresectable gastric carcinoma (MGC): Interim results of a randomized phase III trial (V325). Proc Am Soc Clin Oncol 2003;(abstr 999). 